\title{
Bilim ve Sanat Merkezlerinin Eğitim Programlarının Öğrenci Görüşlerine Dayalı Olarak Değerlendirilmesi
}

\begin{abstract}
Erman KAYIŞDAĞ, Macid Ayhan MELEKOĞLU*
Bilim ve Sanat Merkezlerinin Eğitim Programlarının

Öğrenci Görüşlerine Dayalı Olarak Değerlendirilmesi

Özet

Bu araştırmada Bilim ve Sanat Merkezlerine (BILSEM) devam eden öğrencilerin uygulanan eğitim programlarından ürün, süreç, içerik gibi değişkenler açısından memnuniyet derecesini ölçmek amaçlanmıştır. Nicel araştırma desenlerinden tarama araştırma yöntemi çalışmanın yöntemini oluşturmaktadır. Bulgularda ölçek toplam puanı ile yapılan analizlere göre öğrencilerin görüşleri cinsiyet ve kuruma devam edilen haftalık ders saati açısından anlamlı farklılık tespit edilmiş olup, il değişkeni analizinde de genel ve il bazında eksiklikler tespit edilmiştir. Araştırmada kız öğrencilerin erkeklerden program memnuniyetinin daha yüksek olduğu, 8 ders saati programa devam eden öğrencilerin memnuniyetinin daha yüksek olduğu, eğitim kademesinde anlamlı bir farklılık bulunmadığı tespit edilmiştir. Tespit edilen sonuçlar üzerinden BILSEM eğitim

\author{
Evaluation of Science and Art Centers' Education Prog- \\ rams Based on Student Opinions \\ Abstract
}

In this research, it was aimed to determine the degree of satisfaction of the students attending the Science and Art Centers (BILSEM) in terms of variables such as product, process and content from the applied training programs. This study was designed according to the quantitative research design and survey research method was used. According to the analyzes made with the total scale of the scale, there was a significant difference between the views of the students in terms of sex and the weekly course hour. In the research, female students' satisfaction with the program is higher than that of the male students; It was found that there was no significant difference in education level. It is recommended to eliminate the deficiencies of BILSEM training programs through the determined results.
\end{abstract} programlarının eksikliklerinin giderilmesi önerilmektedir.

Anahtar Kelimeler: Özel Yetenek, BILSEM, Program Değerlendirme

\section{Giriş}

Özel eğitimin çok çeşitli tanımları olmakla birlikte ülkemizde 1997 yılında yayımlanan 573 sayılı Kanun Hükmünde Kararnamenin (KHK) 3. maddesinin b fıkrasında yer aldığı şekilde "Özel eğitim gerektiren bireylerin eğitim ihtiyaçlarını karşılamak için özel olarak

*Erman KAYIŞDAĞ, Arş. Gör, Eskişehir Osmangazi Üniversitesi, Özel Eğitim Bölümü, ekayisdag@gmail.com, 00000002-7319-5078, Macid Ayhan MELEKOĞLU, Doç. Dr., Eskişehir Osmangazi Üniversitesi, Özel Eğitim Bölümü, mamelekoglu@ogu.edu.tr, 0000-0002-9933-5331 
yetiştirilmiş personel, geliştirilmiş eğitim programları ve yöntemleri ile onların özür ve özelliklerine uygun ortamlarda sürdürülen eğitimdir" ifadesiyle açıklanmaktadır. Bu ifade ile özel eğitim gereksinimi olan çocukların ihtiyaç duydukları planlanmış bütün öğretim faaliyetlerinin özel eğitim kapsamında verilmesi gerektiği açıklanmaktadır (Akçamete, 2009). Ülkemizde özel eğitim kapsamında değerlendirilebilecek ilk çalışmaların 1889 yılında İstanbul Ticaret Mektebi içerisinde faaliyet göstermeye başlayan işitme engelliler okulu ile başladığı görülmektedir. Bu okula sonraki yıllarda görme engelliler ile ilgili bir bölüm eklenmiş olsa da 1920'li yıllarda bu okulun faaliyeti sonlandırımıştır. 1920-1950 yılları arasında özel eğitim hizmetlerinin özel eğitim okulları aracılığıyla gerçekleştiği görülmektedir. Bu kapsamdaki ilk okul 1921 yılında İzmir'de açılan Özel İzmir Sağırlar ve Körler Okuludur. 1950 yılından sonra ise özel eğitim hizmetleri ile ilgili uygulamalar Milli Eğitim Bakanlığı (MEB) İlköğretim Genel Müdürlüğü bünyesinde kurulan bir şube aracılığı ile devam etmiştir. 1980 yılında ise Özel Eğitim Genel Müdürlüğü kurulmuş olup bu müdürlük 1982 yılında daire başkanlığına, 1983 yılında Özel Eğitim ve Rehberlik daire başkanlığına, 1992 yılında ise özel eğitimin artan önemine ve öğrenci sayısına cevap verebilmek amacıyla günümüzdeki adı olan Özel Eğitim ve Rehberlik Hizmetleri Genel Müdürlüğü’ne dönüştürülmüştür (MEB, 2010).

573 sayılı Özel Eğitim Hakkında Kanun Hükmünde Kararname (KHK) ile özel eğitimle ilgili temel ilkeler belirtilmiştir. Bu ilkeler; özel eğitime ihtiyacı olan tüm bireylerin ilgi, istek ve yeterlilikleri doğrultusunda özel eğitim hizmetlerinden yararlanmasını, eğitime erken yaşta başlamasını, bireyleri sosyal çevrelerinden ayırmadan eğitim faaliyetlerinin yürütülmesini, bireylerin performansına bağlı olarak gerekli uyarlamalar yapılarak akranlarıyla birlikte eğitim görmesini, eğitimin kesintisiz devam etmesi için kurum ve kuruluşlarla iş birliği içinde olmayı, eğitimin bireyselleştirilmiş eğitim planları aracılığı ile yürütülmesini, eğitim sürecinde ailenin aktif bir şekilde süreçte yer almasını, özel eğitim politikalarının geliştirilmesi ve bireylere yönelik etkinlik gösteren sivil toplum örgütlerinin görüşlerinin alınmasını, bireylerin toplumla etkileşim ve uyumunun sağlanması konularına dikkat çekmektedir (MEB, 1997).

Özel eğitimin neden gerekli olduğu, özel eğitimle bireylere hangi istendik davranışların kazandırılmak istendiği sorusu ile yakından ilgilidir (Atiker, 1995). Günümüzde toplumlarda kişiye verilen önemin artmasıyla birlikte bireyselleşme de artmaktadır. Bu bağlamda genel nüfusun yaklaşık \%10 ila \%12'sini oluşturan özel gereksinimli bireylerin de ihtiyaç duydukları eğitiminin sağlanması önem taşımaktadır. Bu ihtiyaca bağlı olarak ülkemizde son 50 yıl içerisinde özel gereksinimli bireylerin eğitimlerine yönelik kapsamlı yönetmelik ve kanunların yürürlüğe girdiği görülmektedir. Özel eğitim sınıfları, iş uygulama okulları ve Bilim ve Sanat Merkezleri (BILSEM) gibi uygulamaların yürürlüğe sokulması ile özel eğitim 
gereksinimli bireylerin hem eğitim ihtiyaçlarının karşılanması hem de toplumla uyumlu mutlu bireyler olarak yaşamaları hedeflenmektedir (MEB, 2006).

\section{1 Özel Yetenekli Bireyler ve Özel Yetenekli Bireylere Yönelik Eğitimin Önemi}

Özel eğitim ile özel eğitime gereksinim duyan tüm öğrencilerin kendilerine uygun eğitim almaları hedeflenmektedir. Bu açıdan özel yetenekli bireylerin keşfedilmesi ve eğitilmesi de özel eğitimin hedefleri arasında yer almaktadır. Alanyazında özel yetenek teriminin yanı sıra üstün zekâ ve üstün yetenek gibi terimler de kullanılmaktadır. Fakat Milli Eğitim Bakanlığı güncel mevzuatta özel yetenek terimini kullandığı için bu makalede de bu gruptaki tüm öğrencileri ifade etmek üzere özel yetenek terimi kullanılacaktır. Özel yetenek kavramının tanımı incelendiğinde alanyazında pek çok farklı tanıma yer verildiği görülmektedir. Tanımların hala gelişerek devam etmesi önemlidir. Özel yetenekli öğrenciler için oluşturulacak eğitim programları bu kavrama yönelik yapılan tanımlarla yakından ilgilidir (McClellan, 1985). Çeşitli özel yeteneklilik tanımlarına bakıldığında ise Yılmaz ve Çaylak (2009)'a göre özel yetenekli bireyler sanat, liderlik ve yaratıcılık özellikleri ön planda olan, farklı alanlarda yüksek performans gösteren ve eğitim ihtiyaçlarını karşılayacak etkinliklere ihtiyaç duyan bireylerdir. Davis (2011) tarafından yapılan bir tanımlamada ise özel yetenekli bireyler bir ya da daha fazla zekâ türünden ortalamaya kıyasla daha yüksek performans gösteren bireylerdir. Üstün Zekâlı Çocuklar Ulusal Konseyi'nin tanımına göre ise özel yetenekli çocuklar bir ya da daha çok alanda üstün başarı göstermiş ya da gösterme ihtimali olan çocuklardır (Sak, 2014).

Özel eğitim kapsamında kabul edilen zihin yetersizliği, işitme yetersizliği, görme yetersizliği, öğrenme güçlüğü ve otizm spektrum bozukluğu olan öğrencilerin kendilerine uygun eğitim almaları gerektiği gibi, özel yetenekli bireyler de özelliklerine ve farklılıklarına uygun eğitim hizmeti almalıdır. Bu farklılı̆ın ortaya çıkması ise ancak özel yetenekli bireylere göre hazırlanmış, onların bilgi, beceri ve yeteneklerini geliştirecek eğitim programları aracılığı ile olabilecektir (Kontaş ve Yağcı, 2016). Toplumlarda insanlar tarafından gerçekleştirilen birçok çalışma ve yapılan buluşların özel yetenekli bireyler tarafından gerçekleştirildiği ve özel yetenekli bireyler tarafından hayata geçirilen bilimsel çalışmalar dikkate alındığında devletlerin bu bireyler için yaptığı yatırımlar özel yetenekli bireylerin yararına olduğu kadar bu bireylerin içinde bulunduğu toplumlara da yarar sağlamaktadır (Clark, 2013).

Özel yetenekli bireylerin eğitiminde toplum tarafından dile getirilen bir görüş özel yetenekliler eğitiminin elitleşmeye neden olmasıdır. Bazı uzmanlar özel yetenekliler eğitiminin toplumlarda çeşitli farklılıklara yol açabileceğini ve seçkin bir zümre oluşturabileceğini belirtmiştir. Fakat bu durum sadece akademik olarak değerlendirilmemelidir. Akademik alanlar dışında sanat ve spor gibi farklı alanlarda başarı gösteren özel yetenekli bireylerin varlığı toplum içinde herhangi bir kötü sonuca neden olmamaktadır (Sak, 2014). 
Erman KAYIŞDAĞ | Macid Ayhan MELEKOĞLU

\section{2. Özel Yetenekli Bireylere Yönelik Eğitim Programı Geliştirilmesi ve Değerlendir- mesi}

Özel yetenekli bireylerin eğitimlerinde kullanılacak etkili bir programın geliştirilmesi ve uygulanma süreci ve programın değerlendirilmesi özel yetenekli çocukların keşfedilmesi gibi önemli bir ihtiyaçtır. Bu aşamaların özel yetenekli bireylerin, bu bireylerin öğretmenleri ve aileleri gibi paydaşların katılımı ile planlanması ve yürütülmesi gerekmektedir (Clark, 2013).Özel yetenekli bireyler için hazırlanan eğitim programlarının etkililiğinin ölçülmesi önemli bir gereklilik olmasına rağmen uzmanlar tarafından ihmal edilen bir konu olmaktadır (Sak, 2014). Clark (2013) özel yetenekliler için program geliştirme aşamalarında dikkat edilecek yedi önemli konu olduğunu belirtmiştir. Bunlar kısaca şu şekildedir;

1- Program geliştirmek için eldeki kaynaklar kontrol edilmelidir. Program geliştirme ve uygulama sürecinde gerekli olacak her türlü kaynağa sahip olunmalıdır. Gereksinimleri karşılayacak okullar, program için gerekli araç gereç ve alanda uzman öğretmenler olmaması halinde etkili bir program oluşturulamaz.

2- Özel yeteneklilik çok boyutlu bir özellik olduğundan bazı öğrencilerin akademik becerilerde bazılarının ise sanat ve spor gibi alanlarda üstün performans gösterdiği bilinmektedir. Bu açıdan öğrencilerin farklılıklarına göre tanılama yapılarak öğrenciler uygun programlara yerleştirilmelidir.

3- $\quad$ Programın değerlendirme sürecinin etkili olabilmesi için programın geliştirilmesi aşamasında amaçlar, beceriler ve beklenen çıtılar önceden belirlenmelidir.

4- Özel yeteneklilere yönelik eğitim stratejilerinden (hızlandırma, zenginleştirme, gruplama) hangisi programın temelini oluşturacaksa o stratejiye ait hedef kazanımlar ve araç gereçler programda yer almalıdır.

5- Hedef davranışları kazandırmak üzere programı uygulayacak uzmanlarla ilgili beklentiler ve ölçütler belirlenmeli ve bu ölçütlere göre görev alacak personel seçilmelidir.

6- Programın etkililiğini ölçemeye yönelik çalışmalar önceden planlanmalı ve bu değerlendirmede öğrenciler de dâhil edilerek tüm katılımcıların görüşlerini kapsayacak şekilde gerçekleştirilmelidir.

7- Programın başarılı olması sadece öğrencilere ve görev yapan uzmanlara bağlı olmayıp ebeveynler de dâhil olmak üzere tüm paydaşların aktif katılımı sağlanmalıdır. Program kendi içeriğine uygun olarak gezi, konferans ziyaret gibi etkinliklerle de desteklenmelidir.

Program değerlendirmeye yönelik soruların belirlenmesi, program geliştirme sürecinin yol haritasını oluşturmaktadır. Özel yetenekli bireyler için eğitim programlarının temel standartlar baz alınarak değerlendirme soruları belirlenir (Renzulli, 2009). Bununla birlikte 
özel yetenekli öğrenciler için oluşturulan eğitim programlarının bazı standartlara sahip olması gerekmektedir. Bunların ilki etkili bir programa uygun olacak şekilde amaçların ve hedef davranışların belirlenmesi olmalıdır. Hedefler tüm paydaşların görüşleri alınarak sadece tek görüş etrafında şekillenmemesi açısından önemlidir. Ayrıca hedeflerin açıkça yazılması hem programı uygulayacak uzmanların işini kolaylaştıracak hem de programın değerlendirme sürecini kolaylaştıracaktır. Bir diğer standart ise tanılamadır. Programı uygulayacak uzman ve öğretmenlerin özel yetenekli öğrencilerin özelliklerini yakından bilmeleri önemli olduğu gibi tanılama da birden çok tanılama aracı ile objektif şekilde yapılmalıdır. Programın geliştirilmesi için var olan bütçe sadece programın geliştirilmesine dönük ve programda yer alan tüm öğrenci ve öğretmenlerin gelişimi için harcanmalıdır (Clark, 2013). Eğitim programlarının geliştirilmesi ve hayata geçirilmesi kadar programın etkililiğinin değerlendirilmesi de önemli bir husus olarak dikkat çekmektedir (Gözütok, 2011).

Özel yetenekli öğrenciler için hazırlanan eğitim programlarının değerlendirilmesi önem taşıyan bir konudur. Programda yer alan öğrencilerin yetenekli olup olmadıkları, yeteneklerine göre bir programda eğitim alıp almadıkları, programın ve eğitim içeriğinin özel yetenekli öğrenciler için uygun olup olmadığı, programı uygulayacak olan uzmanların özel yetenekliler eğitimi konusunda yetkin olup olmadığı gibi konulardır. Bu sorular ancak etkili bir program değerlendirilmesi ile yanıt bulabilecektir. Program değerlendirmenin dört aşaması bulunmaktadır. Program öncesi değerlendirme, programdan beklenti, programa alınması planlanan öğrencilerin tanılanması, programın hedeflerinin ve programda kullanılması planlanan araç gereçlerin ve değerlendirme yöntemi gibi bileşenlerin incelenmesi şeklinde olmaktadır. Program boyu değerlendirme, programın uygulama süreci içerisinde zaman zaman yapılan değerlendirme aşamasıdır. Ara değerlendirme ise program boyu değerlendirmeye benzemekle birlikte programın sürdürülmesi esnasında ortaya çıkan ve tahmin edilemeyen sorunların değerlendirilmesi için yapılmaktadır. Son olarak program sonu değerlendirme ise programın uygulanması sona erdikten sonra süreç içerisinde toplanan verilerin değerlendirilmesidir (Sak, 2014).

Özel yetenekli öğrenciler için uygulanan programlarının değerlendirilmesi iki şekilde olmaktadır. İlki olarak program etkililiğinin değerlendirilmesi hususudur. Bu değerlendirmede program içerisinde yer alan ve programı oluşturan bileşenler değerlendirilir. Bu bileşenler hedef ve davranışların değerlendirilmesi, tanılamanın değerlendirilmesi, hizmetin değerlendirilmesi ve paydaşların değerlendirilmesidir. İkincisi ise eğitim ve öğretim faaliyetlerinin değerlendirilmesi sürecidir. Eğitim programları içindeki bazı standartlar etkili bir değerlendirme için eksik kalmaktadır. Bu sebeple de özel yetenekli öğrenciler için hazırlanmış programlara yönelik yapılan değerlendirme işlemi daha zor olmaktadır (Clark, 2013). Program değerlendirme aynı zamanda programın geliştirilmesinde görev alan tüm personelin değerlendirilmesi şeklinde de olabilmektedir. İlgili personelin görev ve sorum- 
Erman KAYIŞDAĞ | Macid Ayhan MELEKOĞLU

lulukları incelendiğinde, okul yöneticilerinin özel yetenekli bireylere kendi okullarında verilen eğitimin içinde bulunulan ülkenin eğitim hedefleriyle uygun olup olmaması konusuna dikkat etmek, okuldaki eğitim öğretim hizmetlerinin etkili olması konusunda gerekli tedbirleri almak, ders programı oluşturmak ve öğrenci başarı durumunu takip etmek gibi çeşitli sorumlulukları bulunmaktadır. Programın yürütülmesinde görev alan öğretmenlerin ise öğrencilere sınıf ortamında bireysel farklılıklarına göre rehberlik hizmetini sağlamak, öğrencilerin sınıf içi ders ve başarı durumlarını takip etmek ve mesleki anlamda kendilerini geliştirmek gibi çeşitli sorumlukları bulunmaktadır (Kristie ve Virginia, 2012).

\section{3. Özel Yetenekliler Eğitiminde Program Değerlendirme Modelleri}

Özel yetenekli bireylerin eğitimine yönelik eğitim programları için çeşitli program değerlendirme modelleri de bulunmaktadır. Bunlardan ilki Tyler tarafından 1940 yılında kendi programı üzerinden geliştirilen değerlendirme modelidir (Akgül, 2017; Erden 1998). Tyler'in değerlendirme modelinin merkezinde hedeflerin yer aldığı görülmektedir. Tyler bir eğitim programının dört soru üzerinden şekillenmesi gerektiğini ifade etmektedir. Bu sorular, planlanan hedef davranışlar, eğitimsel etkinlikler, bu etkinliklerin öğrencilere yönelik sunumu ve hedeflerin değerlendirmesinin nasıl gerçekleştirileceğidir. Tyler kalıcılığın ve süreç içindeki takibin gerekli olduğu inancıyla program değerlendirmenin program başlamadan önce ve programın uygulanması bittikten sonra olmak üzere iki kere yapılması gerektiğini ifade etmektedir. Eisner'in eğitsel eleştiri modeli ise eğitim programları vasıtasıyla bireylerin hayatında ortaya çıkan eğitim yaşantılarının açıklanmasını amaçlamaktadır. Program değerlendirme uzmanları program ile birlikte okul ve bireylerin hayatında gerçekleşen yenilikleri, bunların kaynağını, nasıl karşılandığını sorgulamalıdır. Eisner'e göre ayrıca eğitim programlarını değerlendirecek personel mutlaka alanında uzman kişiler olmalıdır. Modelde Eisner veri toplama yöntemi olarak nitel yöntemin daha uygun olduğunu belirtip temalaştırma, betimleme, yorumlama ve değerlendirme olmak üzere dört tema üzerinde yoğunlaşmıştır (Eisner, 1991). Amerika Birleşik Devletlerinde (ABD) Stufflebaum öncülüğündeki bir ekip tarafından geliştirilen başka bir modelde ise özel yetenekliler eğitiminde kullanılan programların çeşitli bağlamlar açısından kontrol edilebilirliği araştırılmaktadır. Modelin dört temel bileşeni bağlam, girdi, süreç ve üründür. Bağlam bileşeni içerik analizi yöntemiyle konuların belirlenmesidir. Girdi bileşeni program için ayrılan maddi kaynakların etkili kullanılıp kullanılmadığının ve hedeflerin öğrenciye uygunluğunun değerlendirilmesidir. Süreç bileşeni program devam ettiği sırada etkililiğini belirlemek amacıyla yapılan değerlendirme olup ürün bileşeni ise programın hedef davranışlara göre gerçekleşip gerçekleşmediğinin değerlendirilmesidir. Model sadece uygulanan eğitim programlarının değerlendirilmesine yönelik olmayıp eğitim sürecinde yer alan tüm paydaşların değerlendirilmesine olanak verecek şekilde geliştirilmiştir. Stufflebaum'un değerlendirme modeli birden fazla değişkeninin kontrolünü ve yeterli sayıda 
personel bulundurmayı gerektirmenin yanı sıra tüm paydaşları içine alan bir model olması nedeniyle diğer modellere göre zor bir model olarak kabul edilmektedir ( Akgül, 2017; Stufflebaum ve Shinkfield, 2007).

Renzulli ve Ward'ın DESDEG modeli ise farklılaştırma temelli eğitim programlarının değerlendirilmesi olarak bilinmektedir. DESDEG modelinde amaçlar, öğrencilere yönelik tanılar ve öğrenci seçimi, uygun ders programları ve öğretmenler gibi bölümler bulunmaktadır. Programa yönelik uygun araç-gereç ve ekipman kullanımı, öğrenci tanılanmasında güncel yaklaşım ve yöntemlerin bulunması, hedeflerin tüm öğrencileri kapsayacak şekilde olması ve görev alacak öğretmenlerin özel yetenekli çocuklarla çalışma deneyimlerinin bulunup bulunmadığının değerlendirilmesidir. Provus farklar yaklaşım modeli ise Malcom Provus tarafından programın sürekliliği amacıyla hazırlanan bir modeldir. Model, standartların belirlenmesi, performans ölçümü, ortaya konulan performansların ölçülmesi ve karşılaştırılması amaçlarını taşımaktadır. Ayrıca maliyet, süreç, ürün, oluşturma ve tasarım gibi altı bileşen modelde yer almaktadır. Bu modele göre yapılan değerlendirmelerde programın tekrar uygulanması, aksayan kısımların değiştirilip devam ettirilmesi gibi kararlar verilerek programın uygulanmasına devam edilebilmektedir (Akgül, 2017; Ornstein ve Hunkins, 2004). Parke ve Buscher tarafından geliştirilen bir başka değerlendirme modeli ise öğrenci öz belgeleme modeli olarak bilinmektedir. Bu model tek başına ya da diğer modellerle birlikte karma olarak kullanılabilmektedir. Bu modelde öğrenci çıktıları üzerinden toplanan veriler ile değerlendirme yapılmaktadır. Model bu açıdan farklı bir model olma özelliği taşımaktadır. Bu açıdan öğrencilere yönelik hedeflerin varlığı, geçerliliği belirlenmiş ölçme araçlarıyla öğrencilerin düzey tespitinin yapılması ve eğitim öğretim ile öğrencilerin kazandıkları akademik beceriler bir program için önem taşımaktadır (Akgül, 2017).

Özel yetenekliler eğitim programlarının değerlendirilmesinde bazı alternatif değerlendirme metotları da bulunmaktadır. Bunlardan ilki öğretmen ve aile temelli değerlendirme metodudur. Bu değerlendirme ile özel yetenek tespiti de yapılabilmektedir. Öğretmenlere göre yetenekli öğrenci meraklı, hızlı ve olay öğrenen, kendi öğrenmesinin sorumluğunu taşıyan ve yaratıcı olan öğrencidir (Shack ve Starko, 1990). ABD'de yetenek aramada aile etkisini inceleyen çalışmalarda SAT ve ACT sınavlarına ait alt testlerden alınan puanların aile katılımı ile paralellik gösterdiği bulunmuştur. Öğretmenler ve aileler değerlendirme sürecinin önemli katılımcıları olduğundan bu süreçteki rolleri önemlidir (Pfeitter, 2015). Bir diğer alternatif değerlendirme metodu olan portfolyo ise özel yetenekliler için oluşturulan eğitim programlarının değerlendirme sürecinde öğrencilere ait yetenek, beceri ve ürünlerle ilgili değerlendirme sürecine katkı sunulmaktadır (Johnsen, 1996; 2008). Portfolyaların birçok değerlendirme metoduna göre daha geçerli bilgiler verdiği bilinmektedir. Portfolyoları özel yetenekli çocukların eğitiminde öğrencilerin yetenek tespiti, öğrencilerin gösterdiği gelişimin izlenmesi ve değerlendirilmesi, program etki- 
Erman KAYIŞDAĞ | Macid Ayhan MELEKOĞLU

lilik ve değerlendirilmesi gibi çeşitli amaçlarla kullanılmaktadır. Portfolyoların değerlendirilmesi yapılırken genel kullanım yapılabileceği gibi kısmi ayrıntı ya da belirlenen birkaç özelliğe göre de değerlendirme yapılabilmektedir (Wiig, 2000).

\subsection{Bilim ve Sanat Merkezleri (BILSEM)}

Bilim ve Sanat Merkezleri (BILSEM) ülkemizde özel yetenekli çocukların eğitimi konusunda hizmet veren ve Milli Eğitim Bakanlığı'na (MEB) bağı devlet okullarıdır. BíLSEM'lerde ilkokula, ortaokula ve liseye devam eden öğrencilerin mevcut kapasitelerini en üst seviyeye çıkarmak amacıyla eğitim hizmet verilmektedir. BiLSEM'ler MEB tarafından nüfusu 100.000 'i aşan yerleşim merkezlerinde fiziki ve bölgesel şartlar dikkate alınarak valiliklerin teklifi üzerine kurulmaktadır. BiLSEM'lerde eğitim, özel yetenekli öğrenciler için hazırlanmış Bireyselleştirilmiş Eğitim Programları (BEP) temelinde sürüdürülmektedir. Öğrencilerin mevcut potansiyellerinin geliştirilmesinin yanında üst düzey düşünme becerilerinin kazandırılması, Türkçeyi kendini ifade edebilme amacıyla kurallarına uygun kullanma gibi hedef beceriler de yer almaktadır. BiLSEM'lere devam eden özel yetenekli öğrenciler aynı zamanda örgün eğitime (ilkokul, ortaokul ya da lise) devam ettiği için BíLSEM'lerdeki ders zamanları okullarıyla çakışmayacak şekilde hafta sonu ya da hafta içi akşam da dahil olmak üzere planlanır. BiLSEM'lerde eğitim grup eğitimi olarak verildiği gibi bireysel eğitim de verilebilmektedir. Bu dersler öğrencilerin potansiyellerine uygun olacak şekilde yaratıcılıklarını geliştirici çalışmaları ya da proje tabanlı çalışmaları kapsayacak şekilde devam etmektedir. Özel yetenekli öğrenciler BíLSEM'lerde uyum, destek eğitimi, bireysel yeteneklerin farkında olma, proje yönetimi ve yetenekleri geliştirme olmak üzere 5 programa alınmaktadır. Öğrencilere bu programlar ile kuruma uyum sağlamaya, öğrencilerdeki mevcut becerilerini geliştirmeye, yeteneklerini fark etmeye, ve farklı bir çok gelişime yönelik çalışmalar farklı öğretim ilke ve teknikleri ile kazandırılmaktadır.

Özel yetenekli çocuklara yönelik eğitim programlarının değerlendirilmesi önemli bir gerekliliktir. Bu değerlendirme özel yetenekli bireylerin sahip olduğu potansiyeli doğru kullanabilme açısından önem taşımaktadır. Uygarlığın gelişiminde sahip oldukları potansiyeller nedeniyle ülkeleri adına önemli katkılar yapabilecek bu öğrencilerin eğitiminin ihmal edilmesi önemli kayıplar doğurabilecektir (Clark, 2013; Sak, 2014). Bu açıdan düşünüldüğünde etkili bir program değerlendirme ile özel yetenekli öğrencilere yönelik uygulanan eğitim programlarının değerlendirilmesi ve gerekli düzenlemelerin yapılması önem taşımaktadır.

Bu araştırmada Bilim ve Sanat Merkezlerine (BILSEM) devam eden öğrencilerin uygulanan program hakkındaki amaç, içerik, süreç, öğrenme ortamı, öğretmen ve değerlendirme bileşenleri açısından düşünceleri ve eğitim programlarından memnuniyet derecele- 
rinin belirlenmesi amaçlanmıştır. Bu amaç çerçevesinde aşağıdaki araştırma sorularına cevap aranmıştır:

1-BILSEM'lerde uygulanan eğitim programlarının değerlendirilmesine yönelik öğrenci memnuniyet düzeyleri öğrencilerin sınıf düzeyine göre farklılaşmakta mıdır?

2-BILSEM'lerde uygulanan eğitim programlarının değerlendirilmesine yönelik öğrenci memnuniyet düzeyleri öğrencilerin BiLSEM'e devam etme sürelerine göre farklılaşmakta midır?

3-BILSEM'lerde uygulanan eğitim programlarının değerlendirilmesine yönelik öğrenci memnuniyet düzeyleri öğrencilerin BiLSEM'de gördükleri ders saati sayısına göre farklılaşmakta mıdır?

4-BILSEM'lerde uygulanan eğitim programlarının değerlendirilmesine yönelik öğrenci memnuniyet düzeyleri öğrencilerin cinsiyetlerine göre farklılaşmakta mıdır?

5-BILSEM'lerde uygulanan eğitim programlarının değerlendirilmesine yönelik öğrenci memnuniyet düzeyleri öğrencilerin eğitim aldıkları illere göre farklılaşmakta mıdır?

\section{Yöntem}

\subsection{Model}

Bu çalışma nicel araştırma desenlerinden tarama araştırma yöntemi kullanılarak gerçekleştirilmiştir. Tarama araştırmaları bir olay, durum veya nesnenin neyle ilgili olduğunu betimlemeye yönelik araştırmalardır (Karasar, 2009). Tarama çalışmaları mevcut durum ya da durumların ortaya çıkarılmasına yönelik gerçekleştirilmektedir (Sönmez ve Alacapınar, 2011).

\subsection{Evren ve Örneklem}

Bu çalışmanın evrenini 2016-2017 eğitim öğretim yılında BiLSEM'lerde eğitim öğretime devam eden her yaş ve sınıf düzeyindeki öğrenciler oluşturmaktadır. Çalışmanın örneklemini ise uygun örnekleme yöntemi (Franklen ve Fallen, 1993) ile seçilen 600 öğrenci oluşturmaktadır. Devlet Planlama Teşkilatı (DPT) tarafından 2002 Avrupa Birliği (AB) çaışmaları kapsamında çalışması yapılan Türkiye İstatiksel Bölge Sınıflandırması (IBBS) ile Türkiye 12 bölgeye ve 26 alt bölgeye ayrılmıştır. Örneklemi belirlemek için bu 12 bölge ve alt bölgeden aşağıda belirtilen iller seçilmiştir. 


\section{Erman KAYIŞDAĞ | Macid Ayhan MELEKOĞLU}

Tablo 1. Örneklem Grubunun Demografik Özellikleri

\begin{tabular}{|c|c|c|}
\hline Sosyo-Demografik Özellikler & $n$ & $\%$ \\
\hline \multicolumn{3}{|l|}{ il } \\
\hline Niğde & 40 & 6.7 \\
\hline Konya & 49 & 8.2 \\
\hline Malatya & 59 & 9.8 \\
\hline Eskişehir & 85 & 14.2 \\
\hline İstanbul & 34 & 5.7 \\
\hline Afyonkarahisar & 54 & 9.0 \\
\hline Adana & 84 & 14.0 \\
\hline Diyarbakır & 53 & 8.8 \\
\hline Kastamonu & 31 & 5.2 \\
\hline Trabzon & 47 & 7.8 \\
\hline Erzurum & 36 & 6.0 \\
\hline Balıkesir & 28 & 4.7 \\
\hline \multicolumn{3}{|l|}{ Eğitim Kademesi } \\
\hline ilkokul & 205 & 34.2 \\
\hline Ortaokul & 353 & 58.8 \\
\hline Lise & 42 & 7.0 \\
\hline \multicolumn{3}{|l|}{ Cinsiyet } \\
\hline Erkek & 320 & 53.3 \\
\hline Kadın & 280 & 46.7 \\
\hline \multicolumn{3}{|l|}{ BILSEM Devam Süresi } \\
\hline 2 yıldan az & 200 & 33.3 \\
\hline $2 \mathrm{yıl}$ & 175 & 29.2 \\
\hline 2 yıldan fazla & 225 & 37.5 \\
\hline Haftalık Saat & & \\
\hline
\end{tabular}




\begin{tabular}{lll}
\hline 8 ders altı & 296 & 49.3 \\
\hline 8 ders & 180 & 30.0 \\
8 ders ve üzeri & 124 & 20.7 \\
\hline
\end{tabular}

\subsection{Veri Toplama Araçları}

Araştırmada ÜYEP-DÖF revize edilmiş sürümü BILLSEM'ler için uyarlanarak kullanılmıştır. ÜYEP-DÖF, Anadolu Üniversitesi'ne bağlı Üstün Yetenekliler Eğitim Programı'nda (ÜYEP) öğrenim gören 6, 7 ve 8. sınıf öğrencilerinin ÜYEP hakkındaki görüş ve memnuniyetlerini ölçmek amacıyla hazırlanmış bir ölçektir (Avcı, 2015, Sak, 2011). ÜYEP-DÖF ölçeğinin kuramsal yapısını oluşturmak amacıyla özel yetenekli öğrencilerin eğitimlerinde kullanılan bilimsel ve etkililiği araştırılmış eğitim öğretim programları incelenmiştir. Uygulamada kullanılan 42 madde için araştırma kapsamında toplanan verilerle hesaplanan Cronbach Alfa güvenilirliği katsayısı 0,938 çıkmıştır. Ölçeğin bu değer açısından uygun olduğu söylenebilmektedir. Ayrıca doğrulayıcı faktör analizi (DFA) sonucu ölçeğin tek boyut olduğu doğrulanmış olup analize ait değerler aşağıdaki tabloda belirtilmiştir.

Tablo 2. Doğrulayıcı faktör analizine ilişkin bulgular

\begin{tabular}{|c|c|c|c|}
\hline Indeks & $\begin{array}{c}\text { Mükemmel Uyum } \\
\text { Ölçütü }\end{array}$ & Kabul Edilebilir Ölçüt & $\begin{array}{c}\text { Araştırma Bul- } \\
\text { gusu }\end{array}$ \\
\hline$\chi^{2} / s d$ & $0-3$ & $3-5$ & 1.85 \\
\hline RMSEA & $.00 \leq$ RMSEA $\leq .05$ & $.05 \leq$ RMSEA $\leq .10$ & .04 \\
\hline $\mathrm{CFI}$ & $.95 \leq \mathrm{CFI} \leq 1.00$ & $.90 \leq \mathrm{CFI} \leq .95$ & .98 \\
\hline TLI & $.95 \leq \mathrm{TLI} \leq 1.00$ & $.90 \leq \mathrm{TLI} \leq .95$ & .88 \\
\hline SRMR & $.00 \leq \mathrm{SRMR} \leq .05$ & $.05 \leq \mathrm{SRMR} \leq .08$ & .04 \\
\hline
\end{tabular}

\subsection{Verilerin Çözümlenmesi}

Araştırma kapsamında ÜYEP-DÖF Ölçeği ile toplanan verilere ait merkezi eğilim ve dağılım ölçülerine ilişkin bulgular aşağıdaki tabloda gösterilmiştir. 
Tablo 3. ÜYEP-DÖF Ölçeğine Ait Betimsel İstatistikler

\begin{tabular}{cc}
\hline \hline istatistik & ÜYEP-DÖF \\
\hline Ortalama & 73.88 \\
Ortanca & 74.63 \\
Mod & 82.10 \\
Varyans & 87.26 \\
En küçük puan & 35.48 \\
En yüksek puan & 90.45 \\
Varyans & 87.26 \\
Çarpıklık & -.583 \\
Basıklık & .318 \\
\hline
\end{tabular}

Tabloya göre ölçekte merkezi dağııım ölçülerinin birbirine yakın olması, çarpıklık ve basıklı̆a ait değerlerin beklenilen aralıkta olması nedeniyle verilerin normal dağılım gösterdiği kabul edildiğinden parametrik testlerle analiz gerçekleştirilmiştir. Normal dağılımda merkezi ölçüler birbirine eşit ya da yakın değerler almaktadır. Çarpıklık ve basıklığa ait değerlerin de -1 ve +1 aralığında olması gerekmektedir (George ve Mallery, 2010).

Çalışmada ölçeğin yapı geçerliliğini tespit etmek amacıyla doğrulayıcı faktör analizi yöntemi kullanıımıştır. Doğrulayıcı faktör analizine göre verilerin çok değişkenli normal dağılım (multivariate normality) göstermediği bulunmuştur (Henze-Zikler $=1.79, p<.05$; Royston $=5677.23, p<.05$ ). Bu nedenle Robust Maximum Likehood (Dirençi Maksimum Olabilirlik) parametre kestirim yöntemi tercih edilmiştir (Mels, 2006).

DFA sonucu ölçeğinin maddeleri üzerinden hesaplanan madde faktör yükleri kullanılarak faktör puanları bulunmuştur. Faktör puanı bulunurken, bir katıımcının ölçeğin birinci maddesine verdiği cevap ile o maddenin faktör yükü çarpılmış ve 42 madde için de aynı işlem uygulanarak aynı öğrencinin faktör puanı hesaplanmışır. Bu işlem çalışmaya katılan 600 öğrenci için tek tek yapılarak tüm katılımcıların faktör puanları hesaplanmıştır. Faktör puanlarının normalliği test edilmiş ve incelenen grup sayısına bağlı olarak t-testi veya varyans analizi (ANOVA) yöntemleri kullanılarak araştırma sorularına cevap aranmıştır.

İki grup arasındaki farklılıklar değerlendirilmek istendiğinde parametrik test ön şartlarını sağladığı durumda bağımsız örneklem t-testi; üç ve daha fazla grup karşılaştırması 
için Tek Yönlü ANOVA ve ikili karşılaştırma testlerinden Tukey testi tercih edilmiştir. Bu istatistiksel yöntemler kullanılırken araştırmacı tarafından istatistiksel anlamlılık düzeyi .05 olarak dikkate alınmıştır.

DFA hesaplanması sonucunda elde edilen madde faktör yüklerinin 42 maddelik ÜYEPDÖF ölçeğinde bulunan toplam değeri ile programdan memnuniyetin en düşük seçeneğini belirten "Katılıyorum" seçeneğine denk gelen 3 değerinin çarpılmasıyla kriter faktör puanı (KFP) hesaplanmıştır. Katılımcıların en düşük seviyede kabul düzeyine karşılık geldiği için "Katılıyorum" ifadesine karşılık gelen 3 değeri kullanılmış ve elde edilen faktör puanının altında ve üstünde kalınan ölçek maddeleri illere göre tek tek yorumlanmıştır.

\section{Bulgular}

\subsection{Sınıf Değişkenine İlişkin Bulgular}

Araştırma kapsamındaki katılımcıların eğitim programından memnuniyet düzeyi ile sınıf değişkeni arasında anlamlı bir fark olup olmadığı Tek Yönlü ANOVA tekniği ile hesaplanmıştır. Tabloda analize ait bulgular yer almaktadır.

Tablo 4. Sınıf Değişkenine İlişkin Betimsel İstatistikler

\begin{tabular}{llllccc}
\hline \hline \multicolumn{1}{c}{ Sınıf Düzeyi } & $N$ & $X$ & SS & Var & \multicolumn{2}{c}{ Çarpıklık Basıklık } \\
\hline İlkokul & 205 & 73.87 & 8.61 & 74.28 & -.554 & 1.734 \\
\hline Ortaokul & 353 & 73.84 & 9.79 & 95.91 & -.610 & .133 \\
\hline Lise & 42 & 74.53 & 9.01 & 81.31 & -.374 & .746 \\
\hline Toplam & 600 & 73.88 & 9.34 & 87.26 & -.583 & .318 \\
\hline
\end{tabular}

Tablo 5. Sınıf Değişkenine illişkin Tek Yönlü ANOVA Tablosu

\begin{tabular}{cccccc}
\hline \hline & $\begin{array}{c}\text { Kareler } \\
\text { Toplamı }\end{array}$ & sd & Kareler Ortalaması & $F$ & $p$ \\
\hline Gruplar Arası & 19,051 & 2 & 9,526 & .109 & .897 \\
\cline { 1 - 4 } Gruplar içi & 52249,47 & 597 & 87,520 & & \\
\hline Toplam & 52268,52 & 599 & & \\
\hline
\end{tabular}

Tablo 5 incelendiğinde araştırmaya katılan bireylerin program memnuniyet düzeyi ile sınıf değişkeni arasında yapılan varyans analizi sonucunda istatistiki olarak anlamlı bir farklılığın ortaya çıkmadığı görülmektedir $(F(2-597)=.109, p>.05)$. Bu sonuçlara dikkate alındığında sınıf değişkeninin öğrencilerin memnuniyet düzeyleri üzerinde anlamlı bir etkisinin olmadığı görülmektedir. 


\section{Erman KAYIŞDAĞ | Macid Ayhan MELEKOĞLU}

\subsection{BiLSEM'e Devam Etme Süresine Ilişkin Bulgular}

Araştırma kapsamındaki bireylerin eğitim programı memnuniyet düzeyi ile BILSEM'e devam etme süresi değişkeni arasında anlamlı fark olup olmadığı Tek Yönlü ANOVA tekniği ile hesaplanmıştır. Varyans analizine ilişkin bulgular aşağıdaki tabloda yer almaktadır.

Tablo 6. BiLSEM'e Devam Etme Süresi Değişkenine İlişkin Betimsel İstatistikler

\begin{tabular}{lcccccc}
\hline $\begin{array}{c}\text { BiLSEM'e Devam } \\
\text { Etme Süresi }\end{array}$ & $N$ & $X$ & SS & Var & \multicolumn{2}{c}{ Çarpıklık Basıklık } \\
\hline 2 yıldan az & 200 & 74.63 & 9.11 & 83.09 & -.644 & 1.379 \\
\hline 2 yıl & 175 & 72.95 & 9.71 & 94.38 & -.585 & -.155 \\
\hline 2 yıldan fazla & 225 & 73.95 & 9.22 & 85.01 & -.516 & -.100 \\
\hline Toplam & 600 & 73.88 & 9.34 & 87.26 & -.583 & 318 \\
\hline
\end{tabular}

Tablo 7. BiLSEM'e Devam Etme Süresi Değişkenine İlişkin Tek Yönlü Anova Tablosu

\begin{tabular}{cccccc}
\hline \hline & $\begin{array}{c}\text { Kareler } \\
\text { Toplamı }\end{array}$ & sd & Kare Ortalaması & $F$ & $p$ \\
\hline Gruplar Arası & 265,940 & 2 & 132,970 & 1.527 & .218 \\
\hline Gruplar İçi & 52002,58 & 597 & 87,107 & & \\
\hline Toplam & 52268,52 & 599 & & & \\
\hline
\end{tabular}

Tablo 7'i incelendiğinde araştırmaya katılan bireylerin memnuniyet düzeyi ile BíLSEM'e devam etme süresi değişkeni arasında yapılan varyans analizi sonucunda istatistiki olarak anlamlı bir farklılığın ortaya çıkmadığı görülmektedir $(F(2-597)=1,527, p>.05)$. Bu sonuçlara göre bireylerin BILSEM'e devam etme süresi değişkeninin öğrencilerin eğitim programından memnuniyet düzeyi üzerinde anlamlı bir etkisinin olmadığı görülmektedir.

\subsection{BiLSEM'de Devam Edilen Ders Saati Değişkenine ilişkin Bulgular}

Araştırma kapsamındaki bireylerin eğitim programı memnuniyet düzeyi ile BiLSEM'de gördükleri ders saati değişkeni arasında anlamlı fark olup olmadığı Tek Yönlü ANOVA tekniği ile incelenmiştir. Analize ilişkin bulgular aşağıdaki tabloda yer almaktadır. 
Tablo 8. BILSEM’de Devam Edilen Ders Saati Değişkenine İlişkin Betimsel İstatistikler

\begin{tabular}{lcccccc}
\hline \hline $\begin{array}{c}\text { BiLSEM'de devam } \\
\text { edilen ders saati }\end{array}$ & $N$ & $X$ & SS & Var & \multicolumn{2}{c}{ Çarpıklık Basıklık } \\
\hline $\begin{array}{l}8 \text { ders altı } \\
8 \text { ders }\end{array}$ & 296 & 72.74 & 9.10 & 82.92 & -.464 & .101 \\
\hline 8 ders ve üzeri & 180 & 75.67 & 9.34 & 87.34 & -.689 & .803 \\
\hline Toplam & 124 & 74.02 & 9.54 & 91.08 & -.823 & .556 \\
\hline
\end{tabular}

Tablo 9. BILLSEM'de Devam Edilen Ders Saati Değişkenine İlişkin Tek Yönlü ANOVA Tablosu

\begin{tabular}{cccccc}
\hline \hline & $\begin{array}{c}\text { Kareler } \\
\text { Toplamı }\end{array}$ & sd & Kareler Ortalaması & $F$ & $p$ \\
\hline $\begin{array}{c}\text { Gruplar } \\
\text { Arası }\end{array}$ & 967,019 & 2 & 483,510 & 5.627 & .004 \\
\hline Gruplar i̇çi & 51301,502 & 597 & 85,932 & & \\
\hline Toplam & 52268,521 & 599 & & & \\
\hline
\end{tabular}

Tablo incelendiğinde araştırmaya katılan bireylerin program memnuniyet düzeyi ile BiLSEM'de devam ettikleri ders saati değişkeni arasında yapılan tek yönlü ANOVA analizi sonucunda istatistiki olarak anlamlı bir farklılık olduğu görülmektedir ( $F(2-597)=5.627$, $p<.05)$. Etki büyüklüğü 0,31 olarak hesaplanmıştır. Diğer bir ifade ile ders saati değişkeninin öğrencilerin eğitim programlarından memnuniyet düzeyi üzerinde anlamlı bir etkisinin olduğu ve bu etkinin orta seviyede bir etki olduğu ifade edilmektedir. Anlamlı farklılığın hangi gruplar arasında olduğunu belirlemek amacıyla Post Hoc testlerinden Tukey testi sonucunda, BiLSEM'lere haftalık 8 ders altında ve 8 ders devam eden öğrenciler arasında anlamlı farkın 8 ders saati devam eden öğrenciler lehinde olduğu hesaplanmıştır. Tukey testi sonucuna ait bulgular aşağıdaki tabloda bulunmaktadır.

Tablo 10. Haftalık Ders Saati Değişkenine İlişkin Tukey Test Sonucu

\begin{tabular}{|c|c|c|c|c|}
\hline Haftalık Saat & Haftalık Saat & Standart Hata & Ortalama Farklar & $p$ \\
\hline 8 ders altı & 8 ders & .87619 & -2.93467 & .002 \\
\hline
\end{tabular}


Erman KAYIŞDAĞ | Macid Ayhan MELEKOĞLU

\begin{tabular}{ccccc}
\hline \hline 8 ders altı & 8 ders üzeri & .99162 & -1.28498 & .398 \\
\hline \multirow{2}{*}{8 ders } & 8 ders altı & .87619 & -2.93467 & .002 \\
\cline { 2 - 5 } 8 ders & 8 ders üzeri & 1.08185 & 1.64969 & .280 \\
\hline
\end{tabular}

\subsection{Cinsiyet Değişkenine iliş̧kin Bulgular}

Araştırma kapsamındaki bireylerin eğitim program memnuniyet düzeylerinin cinsiyet farklılığı açısından incelenmesinde bağımsız örneklem t- testi kullanılmıştır. Analize ilişkin istatistikler ve bağımsız örneklem $t$ testi sonuçları aşağıdaki tabloda yer almaktadır.

Tablo 11. Cinsiyet Değişkenine İlişkin Betimsel İstatistikler

\begin{tabular}{lcccccc}
\hline \multicolumn{1}{c}{ Cinsiyet } & $N$ & $X$ & SS & Var & \multicolumn{2}{c}{ Çarpıklık Basıklık } \\
\hline Erkek & 320 & 72.50 & 9.36 & 87.73 & -.668 & .632 \\
\hline Kız & 280 & 75.46 & 9.07 & 82.34 & -.497 & -.196 \\
\hline Toplam & 600 & 73.88 & 9.34 & 87.26 & -.583 & .318 \\
\hline
\end{tabular}

Tablo 12. Cinsiyet Değişkenine Göre Bağımsız Örneklem T-Testi Sonuçları

\begin{tabular}{ccccccc}
\hline \hline Gruplar & $N$ & $X$ & $S S$ & $s d$ & $t$ & $p$ \\
\hline Erkek & 320 & 72.50 & 9.36 & 598 & -3.919 & .000 \\
\hline KIz & 280 & 75.46 & 9.07 & & & \\
\hline
\end{tabular}

Kız öğrencilere ait puan ortalaması ile $(X=75.46)$ erkek öğrencilere ait puan ortalaması $(X=72.50)$ arasında anlamlı bir farklılık hesaplanmıştır ( $(598)=-3.919, p<.05)$. Hesaplanan farklılığın etki büyüklüğü $d=.32$ olarak bulunmuştur. Cinsiyet değişkeninin öğrencilerin eğitim programlarından memnuniyet düzeyi üzerinde anlamlı bir etkisinin bulunduğu ve bu etkinin orta seviyede bir etki olduğu görülmektedir.

\section{5. î Değişkenine İlişkin Analiz Bulguları}

Araştırma kapsamındaki bireylerin eğitim programı memnuniyet düzeyi ile il değişkeni arasında anlamlı fark olup olmadığını belirlemek amacıyla yapılan Tek Yönlü ANOVA tekniği kullanılmıştır. Tabloda analize yönelik sonuçlar yer almaktadır. 
Tablo 13. İl Değişkenine illişkin Tek Yönlü ANOVA Tablosu

\begin{tabular}{cccccc}
\hline \hline & $\begin{array}{c}\text { Karelerin } \\
\text { Toplamı }\end{array}$ & sd & Kare Ortalamaları & $F$ & $p$ \\
\cline { 1 - 4 } Gruplar Arası & 2839.762 & 11 & 258.160 & 3.071 & .001 \\
\hline Gruplar İçi & 49428.75 & 588 & 84.063 & & \\
\hline Toplam & 52268.52 & 599 & & & \\
\hline
\end{tabular}

Tablo incelendiğinde araştırmaya katılan bireylerin eğitim programlarından memnuniyet düzeyleri il değişkeni açısından incelendiğinde bireylerin memnuniyet düzeylerinin illere göre değişkenlik gösterdiği bulunmuştur $(F(11-588)=3,071, p<.05)$. Bu farka ilişkin etki büyüklüğü $0.05^{\prime}$ dir. Diğer bir ifade ile il değişkenin öğrencilerin eğitim programlarından memnuniyet düzeyi üzerinde anlamlı bir etkisinin olduğu ve bu etkinin küçük seviyede bir etki olduğu söylenebilir. Anlamlı farklılıklar Tukey testine göre, Niğde-Eskişehir, Trabzon-Niğde, Konya-Balıkesir, Malatya-Balıkesir, Malatya-Kastamonu, Trabzon-Balıkesir illeri arasında olduğu bulunmuştur.

Tablo 14. Kriter Faktör Puanının Öğrenci Bazında Illlere Göre Oranı

\begin{tabular}{ccc}
\hline \hline IL & $\begin{array}{c}\text { Altında } \\
\%\end{array}$ & $\begin{array}{c}\text { Üstünde } \\
\%\end{array}$ \\
Niğde & 27 & 73 \\
Konya & 57 & 43 \\
Malatya & 53 & 47 \\
Eskişehir & 37 & 63 \\
İstanbul & 36 & 64 \\
Afyon K. & 32 & 68 \\
Adana & 31 & 69 \\
Diyarbakır & 34 & 66 \\
Kastamonu & 39 & 61 \\
Trabzon & 54 & 46 \\
Erzurum & 37 & 63 \\
Balıkesir & 25 & 75 \\
\hline
\end{tabular}




\section{Erman KAYIŞDAĞ | Macid Ayhan MELEKOĞLU}

Tablo incelendiğinde DFA'da madde faktör yüklerine göre elde edilen kriter faktör puanı (67.86) dikkate alındığında Konya, Malatya ve Trabzon illerinde bulunan öğrencilerin yarıdan fazlasının belirlenen kriterin altında kaldıkları bulunmuştur.

Aşağıdaki Tablo 15'te ise illerdeki öğrencilerin 4'lü likert tipli ÜYEP-DÖF ölçeğinin “Kesinlikle Katılmıyorum", "Katılmıyorum", "Katılıyorum" ve "Kesinlikle Katılıyorum" seçeneğine verdikleri cevap sayıları ve bu sayıların genel cevap içindeki oranları gösterilmektedir. Tabloya göre "Kesinlikle Katılmıyorum" ve "Katılmıyorum" seçeneğini işaretleyen öğrencilerinin oranlarının en çok olduğu illerin Niğde, Konya ve Malatya olduğu, en az olduğu illerin ise Kastamonu, Adana ve İstanbul olduğu anlaşılmaktadır.

Tablo 15. illere Göre Cevap Yüzdesi

\begin{tabular}{|c|c|c|c|c|c|c|c|c|}
\hline \multirow[t]{2}{*}{$\overline{i L}$} & \multicolumn{2}{|c|}{$\begin{array}{l}\text { Kesinlikle } \\
\text { Katılmıyorum }\end{array}$} & \multicolumn{2}{|c|}{ Katılmıyorum } & \multicolumn{2}{|c|}{ Katılıyorum } & \multicolumn{2}{|c|}{$\begin{array}{l}\text { Kesinlikle } \\
\text { Katılıyorum }\end{array}$} \\
\hline & Cevap & $\%$ & Cevap & $\%$ & Cevap & $\%$ & Cevap & $\%$ \\
\hline Niğde & 103 & 6.14 & 292 & 17.38 & 416 & 24.76 & 869 & 51.72 \\
\hline Konya & 112 & 5.46 & 342 & 16.61 & 773 & 37.56 & 831 & 40.37 \\
\hline Malatya & 219 & 8.86 & 366 & 14,76 & 809 & 32.64 & 1084 & 43.74 \\
\hline Eskişehir & 212 & 5.93 & 495 & 13.86 & 1256 & 35.18 & 1607 & 45.01 \\
\hline İstanbul & 51 & 3.59 & 178 & 12.46 & 558 & 39.07 & 641 & 44.88 \\
\hline Afyon & 183 & 8.06 & 252 & 11.11 & 653 & 28.79 & 1180 & 52.02 \\
\hline Adana & 137 & 3.90 & 414 & 11.73 & 1209 & 34,26 & 1768 & 50.11 \\
\hline Diyarbakır & 131 & 5.90 & 257 & 11.54 & 761 & 34.18 & 1077 & 48.38 \\
\hline Kastamonu & 30 & 2.32 & 116 & 8.90 & 437 & 33.56 & 719 & 55.22 \\
\hline Trabzon & 89 & 4.50 & 300 & 15.22 & 756 & 38.29 & 829 & 41.99 \\
\hline Erzurum & 51 & 3.39 & 166 & 10.97 & 576 & 38.09 & 719 & 47.55 \\
\hline Balıkesir & 86 & 7.31 & 144 & 12.26 & 256 & 21.76 & 690 & 58.67 \\
\hline
\end{tabular}

\section{Sonuç, Tartışma ve Öneriler}

Alanyazın incelendiğinde BíLSEM'lerde görev yapan öğretmenler üzerinde çalışmalar bulunmaktadır. Örneğin Gökdere ve Çepni (2004) tarafından gerçekleştirilen bir araştırmada özel yetenekli öğrencilere fen öğretiminde çalışan öğretmenlerin yeterlilik ve hiz- 
met içi eğitime ihtiyaç duyup duymadıkları incelenmiştir. Araştırmada öğretmenlerin öğretim etkinlikleri proje tabanlı öğrenme, kaynak erişimi gibi konularda öğretimi ve programın uygulanışını doğrudan etkileyen eksiklikleri olduğu bulunmuştur. Araştırmamızda ÜYEP-DÖF ölçeğinin BiLSEM'lerde görev yapan öğretmenlerin alanıyla ilgili bilgi, beceri düzeyinin değerlendirilmesi beklendiği $6,12,17,21,27,34,35$ ve 39. maddelerinde öğrencilerin verdikleri cevaplar illere göre farklılık göstermektedir. BiLSEM'lere öğretmen seçimi konusunda belirlenmiş ortak standartlar bulunmadığı, bir ildeki BiLSEM'de doktora yapmış öğretmen görev yapamazken başka bir ilde lisans mezunu bir öğretmenin görev yapabildiği görülmektedir. Bu nedenle BiLSEM'lerde görev yapan öğretmenlerin gerek alan gerek mesleki bilgileri aynı olmadığından illere göre bu farklılaşmanın nedeni bu temelde düşünülmektedir.

Benzer örneklem grubu ile yapılan başka bir çalışmada ise Sak (2011) ÜYEP programına devam eden 84 öğrencinin programdan memnuniyet düzeyinin yüksek olduğu sonucunu bulmuştur. Aynı şekilde Neihart, Reis, Robinson ve Moon (2002) tarafından yapılan başka bir çalışmada da eğitim programlarının, özel yetenekli çocukların eğitiminde başta problem çözme becerilerinin gelişiminde olmak üzere birçok becerinin gelişmesinde etkili olduğu bulunmuştur. Bu sonuç araştırmamızda da katılımcı öğrencilerin BíLSEM'lerde uygulanan eğitim programından genel olarak memnun oldukları sonucunu ortaya çıkarsa da BILSEM'lerde sadece öğrencilerin tanılanmasının ortak olduğu, çalışmanın geçtiği yıllarda BiLSEM'lerde uygulanan eğitim programlarının ilden ile farklılık gösterdiği bilinmektedir.

Bu çalışmanın sonuçlarında öğrencilerin sınıf düzeyine yönelik bulgularda ilkokul, ortaokul ve lise düzeyleri arasında anlamlı bir fark görülmemiştir. Öğrencilerin tanılanma yılının bilinmemesi ve BíLSEM'e kaç yaşında başladıkları araştırmanın bir sınırlıı̆̆ olarak görüldüğünde anlamlı farkın çıkmamasının nedeninin bu değişkenlere bağlı olarak açıklanabileceği düşünülmektedir. BiLSEM'lere kaç yıldır devam edildiği değişkenine baktığımızda ise iki yıl BiLSEM'e devam eden öğrencilerin iki yıldan az devam edenlere oranla ve iki yıl üzerinde devam edenlerin de iki yıl devam eden öğrencilere oranla faktör puanlarının anlamlı derecede yüksek olduğu görülmüştür. Ataman (1982)'e göre eğitimden yarar sağlanabilmesi erken yaşlarda tanılamayla, eğitime başlama ile olmaktadır.

Çalışmanın cinsiyet değişkenine ait sonuçlarda kız öğrencilere ait faktör puanlarının erkek öğrencilerden daha fazla olduğu hesaplanmıştır. Vatansever Bayraktar ve Doğan (2014) tarafından yapılan bir çalışmada öğrenci ile öğretmen arasındaki iletişim değerlendirme ölçeğinin saygı ve ifade becerisi alt boyutlarında kız öğrencilerin puanlarının erkek öğrencilere göre anlamlı düzeyde yüksek olduğu bulunmuştur. Bu anlamda kız öğrenciler lehine olan bu anlamlı farklılıkların özel yetenekli öğrenciler için de geçerli olduğu anlaşılmaktadır. 


\section{Erman KAYIŞDAĞ | Macid Ayhan MELEKOĞLU}

Alanyazındaki Ayas, Karamustafaoğlu, Sevim ve Karamustafaoğlu (2002) ile Mülayim ve Soran (2002) yaptıkları çalışmalarda ders saati miktarının artırılmasının öğrenciler üzerinde olumlu etkisi olduğu sonucuna ulaşmışlardır. Oysa çalışmamızda ölçek genel puanı üzerinden haftalık 8 ders saati programa devam eden öğrencilerin puanlarının 8 ders saatinin altında devam eden öğrencilere göre anlamlı olarak yüksek olduğu hesaplanmış olup, 8 ders saati ve üzerinde devam eden öğrencilerde ise bu yönde anlamlı bir farklılık görülmemiştir. Bu sonuca göre özel yetenekliler eğitim programlarda ders saatlerinin artırılmasının belli bir düzeye kadar öğrenci açısından olumlu olarak görüldüğü belirli bir düzeyden sonra artmaya devam etmesinin ise öğrenci açısından bir değişikliğe yol açmadığı görülmektedir.

Araştırma yapılan 12 ildeki bulgulardan hareketle;

-Programlarda yer alan derslerin ve konuların öğrencilerin yeni problemler oluşturmasına yeterince katkı sağlamadığı,

-Öğrencilerin program başarılarının nasıl değerlendirileceği konusunda bilgi sahibi olmadıkları,

-Programdaki konularda yapılan çalışmalarda akran değerlendirilmesi çalışmalarına yeterince yer verilmediği,

-Grup çalışmalarında grup öğrencilerinin belirli sürelerde değiştirilerek heterojenliği sağlamada eksikliler olduğu görülmüştür.

Bu bulgulardan hareketle BíLSEM'lerde

-Eğitim programlarının öğrencilerin yeni problemler oluşturarak çözümüne ulaştıracak hedef ve etkinlikleri içermesi gerektiği,

- Akademik başarısı yüksek öğrencilerin ölçme ve değerlendirme konusunda bilgilendirilmelerinin öğrencileri motive ettiği (Göçmen, 2004) göz önüne alınarak eğitim programlarında öğrencilerin program sonucunda edindikleri kazanımların ölçme ve değerlendirilmesinin nasıl yapılacağı konusunun belirtilmesinin gerektiği,

-Eğitim programlarında akran değerlendirme çalışmalarına ağırlık verilmesi gerekmekle birlikte Tarhan ve Kılıç (2014)'e göre okul öncesi dönem ile üçüncü sınıf arası akranların birbirini değerlendirmede zorluklarla karşılaşabileceği göz önünde bulundurularak programlarda akran değerlendirme etkinliklerine dördüncü sınıftan itibaren yer verilmesi gerektiği, 
- Heterojen gruplarda bulunmanın öğrenciler üzerinde akademik ve sosyal becerilerde geliştirici etkisi bulunduğu (Cady, 2011) ve heterojen gruplarda bulunan ve yeteneğinin altında başarı gösteren öğrencilerin grupta bulunan başarısı yüksek arkadaşlarından olumlu olarak etkilendiği ve heterojen gruplar oluşturmanın işbirlikli çalışma becerisi kazandırdığı (Fauziah ve Latief, 2015) göz önünde bulundurularak eğitim programı doğrultusunda yapılan etkinlerde grupların belirli aralıkla değiştirilerek heterojen yapının sağlanması gerektiği,

-Her BILSEM'de farklı olan eğitim programlarının MEB ve üniversitelerdeki ilgili alan uzmanları tarafından oluşturulacak ortak bir eğitim programı ile devam etmesinin gerektiği,

-Her BiLSEM için farklı uygulanan öğretmen seçiminin MEB tarafından tüm BİLSEM'leri kapsayacak şekilde ortak bir standart ve seçme sistemine dönüşmesi gerektiği düşünülmektedir.

\section{Kaynaklar}

Akgül, Ş. (2017). Üstün yetenekliler eğitim programı değerlendirme. S. Emir (Ed), Özel yeteneklilerin eğitiminde program tasarımı içinde (s. 265-298). Ankara: Pegem Yayıncılık.

Ataman, A. (1982). Üstün zekalı çocuklara anne babaları ve öğretmenleri nasıl yardımcı olabilir? Ankara Üniversitesi Eğitim Dergisi, 15(1), 335-344.

Atiker, E. (1995). Bireyselleşme ve toplumsal farklılaşma. İstanbul: İstanbul Üniversitesi Yayınları.

Avcı G. (2015). Üstün yetenekliler eğitim programları değerlendirmeleri öğrenci formunun revize edilmesi ve psikometrik özelliklerinin araştırılması. (Yayınlamanmış yüksek lisans tezi), Anadolu Üniversitesi, Eskişehir.

Ayas, A., Karamustafaoğlu, S., Sevim, S. \& Karamustafaoğlu, M. (2002). Genel kimya laboratuvar uygulamalarının öğrenci ve öğretim elemanı gözüyle değerlendirilmesi. Hacettepe Üniversitesi Eğitim Fakültesi Dergisi, 23, 50-56.

Cady, J. L. (2011). The effects of implementing heterogeneous writing groups in a fifth grade classroom (Yayımlanmamış doktora tezi), Rowan Üniversitesi, Glassboro

Clark, B. (2013). Growing up gifted. Cambridge: Pearson. 


\section{Erman KAYIŞDAĞ | Macid Ayhan MELEKOĞLU}

Davis, F. N. (2011). The influences of the school and home environment on the differences between academically successful and unsuccessful gifted urban high school students. (Yayınlanmamış doktora tezi). Saint Josephs University. Philadelphia.

Eisner, E. W. (1991). The englightened eye: Qualitative inquiry and the enchancement of educational practice. Teachers Colllege Press.

Erden, M. (1998). Eğitimde program değerlendirme. Ankara: Pegem Yayıncılık.

Fauziah, H. \& Latief, M. A. (2015). The effect of working in heterogeneous and homogeneous pairs on the students' writing skill. Arab World English Journal, 6(2), 174-188.

George, D., \& Mallery, P. (2010). SPSS for windows step by step: A simple guide and reference 17.0 update. 10th edition, Boston, MA: Pearson.

Gökdere, M., \& Çepni, S. (2004). Üstün yetenekli öğrencilerin fen öğretmenlerinin hizmet içi ihtiyaçlarının değerlendirilmesine yönelik bir çalışma; bilim sanat merkezi örneklemi. Gazi Eğitim Fakültesi Dergisi, 24(2), 1-14.

Gözütok, D. (2001). Program değerlendirme. M. Gültekin (Ed), Öğretimde planlama ve değerlendirme içinde (s. 175-190). Eskişehir: Anadolu Üniversitesi Yayınları.

Johnsen, S. K. (1996). What are alternative assessments. Gifted Child Today, 19, 12-13.

Johnsen, S. K. (2008). Portfolio assessment of gifted stedents. In J. Van Tassel-Baska (Ed.), Alternative assessments with gifted and talented students (p. 227-257). Waco, TX: Prufrock Press

McClellan, E. (1985). Defining giftedness. Reston, VA: ERIC Clearinghouse on Handicapped and Gifted Children.

Karasar, N. (2009). Bilimsel araştırma yöntemi (20. Baskı). Ankara: Nobel Yayınevi.

Kristie N. S., \& Virginia, B. H. (2012). Gifted program evaluation, a handbook for administrators, coordinators. Texas: Prufrock Press.

Kontaş, H. \& Yağcı, E. (2016). BilLSEM öğretmenlerinin program geliştirme ihtiyaçlarına ilişkin geliştirilen programın etkililiği. Abant İzet Baysal Üniversitesi Eğitim Fakültesi Dergisi, 16(3), 902-923. 
MEB.(1997). 573 sayılı Özel Eğitim Hakkında Kanun Hükmünde Kararname http://orgm.meb.gov.tr/meb_iys_dosyalar/2012_10/10111011_ozel_egitim_kanun_ hukmunda_kararname.pdf adresinden erişilmiştir.

MEB. (2006). Özel Hizmetleri Yönetmeliği http://www.resmigazete.gov.tr/eskiler/2006/05/20060531-2.htm adresinden erişilmiştir.

MEB. (2010). T.C. Milli Eğitim Bakanlığı İç Denetim Birimi Başkanlığı, Bilim ve Sanat Merkezleri Süreci İç Denetim Raporu, http://icden.meb.gov.tr/www/meb-ic-denetimbirimi-baskanligi-faaliyet-raporlari/icerik/13 adresinden erişilmiştir.

Mels, G. (2006). LISREL for windows: Getting started guide. Lincolnwood, IL: Scientific Software International, Inc.

Mülayim, H. \& Soran, H. (2002). Lise 1 biyoloji ders kitapları ve haftalık ders saatleri hakkında öğrenci öğretmen ve okul yöneticilerinin görüş ve önerileri. Hacettepe Üniversitesi Eğitim Fakültesi Dergisi, 23, 185-197.

Neihart, M., Reis, S. M., \& Robinson, N. M. (2002). Social and emotional issues facing gifted and talented students: What have we learned and what should we do now? In Neihart, M., Reis, S. M., \& Robinson, N. M. (eds), The social and emotional development of gifted children: What do we know? Washington: Prufrock Press.

Ornstein, A., \& Hunkins, F. (2004). Curriculum. Boston, MA: Pearson.

Pfeitter I. S. (2015). Essentials of gifted assessment. USA: Wiley.

Renzulli, J. S. (2009). The multiple menu model for developing differentiated curriculum. In J. S. Renzulli, E. J. Gubbins, K. S. McMillen, R. D. Eckerts \& C. A. Little (Ed.), Systems and models for developing programs for the gifted and talented (p.179-211). Mansfeld Center, CT: Creative Learning Press.

Sak, U. (2011). Üstün yetenekliler eğitim programları modeli ve sosyal geçerliği. Eğitim ve Bilim, 36 ( 161) 213-229.

Sak, U. (2014). Üstün zekâlılar özellikleri, tanılanmaları, eğitimleri. Vize Yayıncılık: Ankara.

Schack, G. D. \& Starko, A. J. (1990). Identification of gifted students: An analysis of criteria preferred by pre-service teachers, classroom teachers, and teachers of gifted. Journal for the Education of the Gifted, 13, 346-363. 
Stufflebeam, D. L. \& Shinkfield, A. J. (2007). Evaluation theory models, \& applications. San Francisco, CA: Josseyy-Bass.

Sönmez, V., \& Alacapınar, F., G. (2011). Örneklendirilmiş bilimsel araştırma yöntemleri. Ankara: Anı Yayıncılık.

Tarhan, S. \& Kılıç, Ş. (2014). Üstün yetenekli bireylerin tanılanması ve Türkiye'deki eğitim modelleri. Üstün Yetenekliler Eğitimi ve Araştırmaları Dergisi (UYAD), 2(2), 27-43.

Wiig, E. H. (2000). Authentic and other assessments of language disabilities: When is fair? Reading and Writing Quarterly, 16, 179-210.

Vatansever Bayraktar, H. \& Doğan, C. (2014). Beşinci sınıf öğrencilerinin öğretmenleri ile arasındaki iletişimin değerlendirilmesi. The Journal of Academic Social Science Studies, 30, 237-249. 
EK

\title{
BİLSEM Eğitim Programları Değerlendirme Ölçeği
}

\section{BİLIM VE SANAT MERKEZİ (BILLSEM) EĞİTIM PROGRAMLARI DEĞERLENDIRME FORMU}

Değerli öğrenciler;

$\mathrm{Bu}$ formun amacı Bilim ve Sanat Merkezlerinde uygulanan eğitim programlarını sizin görüşlerinize göre değerlendirmektir. Hiç KatılmıyorumKatılmıyorum-Katılıyorum-Tamamen Katıliyorum seçeneklerinden Sizlere en uygun şıkkı işaretleyiniz. Bu araştırmaya katkı sağladığınız için teşekkür ederiz.

\author{
Arş. Gör. Erman KAYIŞDAĞ \\ Eskişehir Osmangazi Üniversitesi Özel Eğitim Bölümü \\ Özel Yetenekliler Eğitimi Anabilim Dalı \\ (ekayisdag@gmail.com)
}

Sintf: .................

Cinsiyet:..............

Bilsem'e kaç yuldır devam ediyorsunuz? ......................

Bilsem'de haftalık devam ettiğiniz ders saati:................... 


\begin{tabular}{|c|c|c|c|c|}
\hline Maddeler & 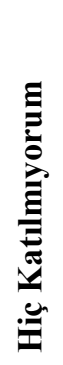 & 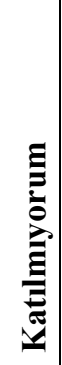 & 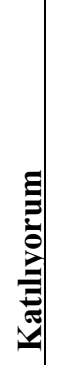 & 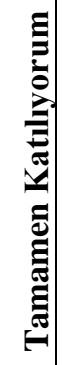 \\
\hline $\begin{array}{l}\text { 1.Programda, beni düşünmeye yönlendiren soyut konulara yer veril- } \\
\text { mektedir. }\end{array}$ & & & & \\
\hline $\begin{array}{l}\text { 2.Programdaki dersler, birçok öğretim yöntemi (anlatım, deney, göste- } \\
\text { ri, gezi, konferans vb.) kullanılarak işlenmektedir. }\end{array}$ & & & & \\
\hline $\begin{array}{l}\text { 3.Programda, iletişim kurma becerilerimizi geliştirmek için çalışmalar } \\
\text { yapmaktayız. }\end{array}$ & & & & \\
\hline $\begin{array}{l}\text { 4.Programda, yaşamla ilgili gerçek sorunların çözümlerine yönelik } \\
\text { çalışmalar yapmaktayız. }\end{array}$ & & & & \\
\hline $\begin{array}{l}\text { 5.Programda, yeni düşünceleri hoş karşılayan bir ortam bulunmakta- } \\
\text { dır. }\end{array}$ & & & & \\
\hline 6.Programdaki öğretmenler, branşlarında bilgilidirler. & & & & \\
\hline 7.Programdaki çalışma ortamları benim özelliklerime uygun değildir. & & & & \\
\hline $\begin{array}{l}\text { 8.Programda yer alan derslerin konuları arasında bağlantılar bulun- } \\
\text { maktadır. }\end{array}$ & & & & \\
\hline 9.Programdaki derslerde, yeni problemler oluşturmaktayız. & & & & \\
\hline $\begin{array}{l}\text { 10.Programdaki başarımızın nasıl değerlendirileceği önceden belirtil- } \\
\text { mektedir. }\end{array}$ & & & & \\
\hline $\begin{array}{l}\text { 11.Programda, kendi tercihlerimize göre çalışmalar yapmamız destek- } \\
\text { lenmektedir. }\end{array}$ & & & & \\
\hline $\begin{array}{l}\text { 12.Programdaki öğretmenler, benim bireysel özelliklerime karşı say- } \\
\text { gıyla yaklaşmaktadır. }\end{array}$ & & & & \\
\hline 13.Programda, birçok bilgiyi kendimiz keşfederek öğrenmekteyiz. & & & & \\
\hline 14.Programdaki derslerde çok çeşitli konulara yer verilmektedir. & & & & \\
\hline 15.Programdaki derslerde, yeni fikirler üretmekteyiz. & & & & \\
\hline 16.Programda, ürün veya proje geliştirirken tercih ettiğim çalışı & & & & \\
\hline
\end{tabular}




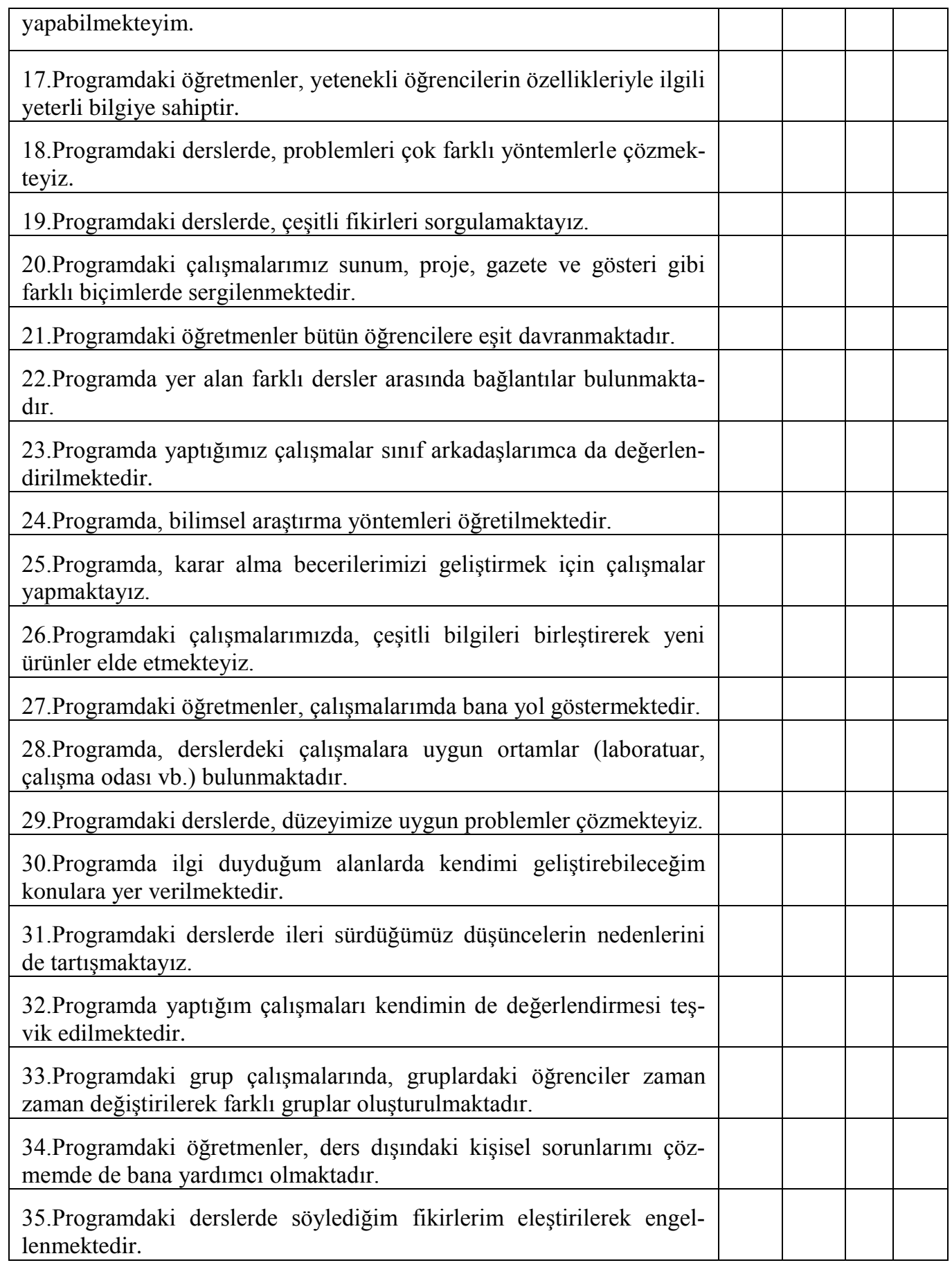




\begin{tabular}{|l|l|l|l|}
\hline 36.Programda gerçek yaşamla ilgili konulara da yer verilmektedir. & & & \\
\hline $\begin{array}{l}\text { 37.Programdaki grup çalışmalarımızda bütün öğrenciler aktif görevler } \\
\text { almaktadır. }\end{array}$ & & & \\
\hline $\begin{array}{l}\text { 38.Programda öğretmenlerin verdikleri problemlerin yanı sıra kendi- } \\
\text { miz de problemler keşfederek çözmekteyiz. }\end{array}$ & & & \\
\hline $\begin{array}{l}\text { 39.Programdaki öğretmenler, geleceğe yönelik okul ve meslek seçimi } \\
\text { gibi planlarım için bana yol göstermektedir. }\end{array}$ & & & \\
\hline 40.Programa isteyerek devam ediyorum. & & \\
\hline $\begin{array}{l}\text { 41.Programdaki konular, kendime örnek alabileceğim bilim insanları- } \\
\text { nın çalışmalarını da (hayatları, eserleri vb.) kapsamaktadır. }\end{array}$ & & & \\
\hline 42.Programın, okul başarıma yararı olmamaktadır. & & & \\
\hline
\end{tabular}

